MT-DP - 2011/12

\title{
The Mandatory Private Pension Pillar in Hungary: An Obituary
}

ANDRÁS SIMONOVITS 


\section{Discussion papers}

MT-DP - 2011/12

Institute of Economics, Hungarian Academy of Sciences

KTI/IE Discussion Papers are circulated to promote discussion and provoque comments. Any references to discussion papers should clearly state that the paper is preliminary. Materials published in this series may subject to further publication.

The Mandatory Private Pension Pillar in Hungary: An Obituary

Author:

András Simonovits

research advisor

Institute of Economics - Hungarian Academy of Sciences

E-mail: simonov@econ.core.hu

March 2011

ISBN 978-615-5024-43-6

ISSN $1785377 \mathrm{X}$ 


\title{
The Mandatory Private Pension Pillar in Hungary: An Obituary
}

\author{
András Simonovits
}

\begin{abstract}
In 1998, the left-of-center government of Hungary carved out a second pillar mandatory private pension system from the original mono-pillar public system. Participation in the mixed system was optional for those who were already working, but mandatory for new entrants to the workforce. About 50 per cent of the workforce joined voluntarily and another 25 per cent were mandated to do so by law between 1999 and 2010. The private system has not produced miracles: either in terms of the financial stability of the social security system, or greatly improved social security in old age. Moreover, the international financial and economic crisis has highlighted the transition costs of pre-funding. Rather than rationalizing the system, the current conservative government de facto "nationalized" the second pillar in 2011 and is to use part of the released capital to compensate for tax reductions.
\end{abstract}

Keywords: social security reform, old age risk, defined contribution plan, privatization, political aspect, Hungary

JEL: H55, J26

Acknowledgement:

The author acknowledges the help of the grant OTKA K81483, and thanks Zoltán Ádám, Ágnes Matits, Gábor Obláth and Judit Spät for detailed comments. The usual disclaimer applies. 


\title{
Kötelező magánnyugdíj-pillér Magyarországon: Gyászjelentés
}

\author{
Simonovits András
}

\section{Összefoglaló}

1998-ban a balközép magyar kormány kihasított egy második pillért (a kötelező magánnyugdíj-rendszert) az eredetileg monopilléres társadalombiztosítási rendszerből. A vegyes rendszerben való részvétel önkéntes volt a már munkában állóknak, de kötelező volt az újonnan belépőknek. A dolgozóknak mintegy 50\%-a csatlakozott önként, majd további 25\%-a kötelezően 1999 és 2010 között. A magánnyugdíj-rendszer nem produkált csodákat, sőt, a nemzetközi pénzügyi és gazdasági válság reflektorfénybe helyezte a tőkésítés átmeneti költségeit. A konzervatív kormányzat - ahelyett, hogy racionalizálta volna a rendszert - valójában államosította a második pillért 2011-re, és a felszabaduló tőkét részben adócsökkentésre használja fel.

Tárgyszavak: második pillér, nyugdíjak, tőkésítés, magánosítás, Magyarország

JEL kódok: H55, J26 


\section{INTRODUCTION}

The partial or full privatization of the pension system with pre-funding has been advocated by many economists, but the World Bank (1994) has had the most decisive impact on the actual reforms performed in Latin America and East-Central Europe (Müller, 1999 and 2003; Fultz, 2002; Schmähl and Horstmann, 2002). The underlying ideas behind such a structural reform were as follows: privatization with pre-funding i) significantly raises the level of savings, especially long-term savings, ii) enhances incentives to work and report earnings, iii) diversifies risks, iv) weakens the adverse impact of long-term population ageing, and v) increases the possibility of making investments in countries with young populations.

With a certain delay, the theoretical critique of the so-called paradigmatic pension reform has appeared in the literature (e.g. Orszag and Stiglitz, 2001; World Bank, 2006; Diamond and Orszag, 2005 and Barr and Diamond, 2008): i) mandatory private pension savings crowd-out voluntary savings for higher-paid workers and are difficult to achieve for those who are lower-paid; ii) the incentives to work and report earnings do not change significantly, because the weight of the private pillar is not large enough and the accompanying tax increases neutralize the remaining incentives; iii) yields and earnings are strongly correlated, undermining the force of diversification; iv) a dropping birth rate weakens real yields, while increasing life expectancy decreases annual private benefits the same way as it does for public benefits; and v) countries with young populations can illafford foreign direct investment and capital export increases the gross foreign debt of the exporting country.

Between 1998 and 2004 most ex-communist countries (notable exceptions were the Czech Republic and Slovenia) carved out the so-called "second pension pillar" from the original mono-pillar public system, but during the recent international financial and economic crisis some of them (the Baltic Republics) temporarily suspended its functioning. At the end of 2010, a former front-runner, Hungary, not only suspended private contributions but essentially closed down the second pillar completely. ${ }^{1}$ This article will describe and analyze the processes that lead to the rise and fall of the second pillar in Hungary. ${ }^{2}$

\footnotetext{
${ }^{1}$ The present article makes extensive use of five earlier articles (Simonovits, 1999, 2001, 2008, 2009 and 2011).

${ }^{2}$ A subjective remark is necessary. This author has never been a proponent of the second pillar, but rejects and protests against its current destruction (which has left only 3 per cent of the original affiliated members in the second pillar associations) as illegitimate, irrational and subversive.
} 
What were the basic factors that called for the creation of the second pillar in Hungary in 1998 ? Before 1998, the country had a universal and progressive public pension system that provided the bulk of support in old age for the bulk of the pensioners. ${ }^{3}$ Note, however, that the World Bank has called into question the redistribution provided by such progressivity, claiming "that upper-income people enter the labor force later in life and live longer after retirement, so they contribute less, receive more than lower-income people [per dollar] over a lifetime" (1994, p. 131).

By 1995, a broad consensus was in agreement that the Hungarian pension system needed important reform. With the type of reform that was chosen in Hungary, a significant - though not dominant - share of the revenues were carved out for the private, funded pillar. In Hungary, the annual transition cost that remained after the parametric reform (which arose as a result of the diversion of contributions from the public system to the private accounts) was financed from general revenues (including taking on debts) and, depending on statistical rules, was significant: 1 to 2 per cent of GDP.

During its 13-year-lifespan, and contrary to high expectations, the second pillar did not produce miracles nor did it constrain the fiscal binges of subsequent Hungarian governments. Among the important items of government overspending, increases in public pensions (most notably the step-by-step introduction of a 13th month benefit during 2003-2006 by the socialist-liberal coalition) played an important role. Although the re-elected coalition reduced the budget deficit to acceptable levels between 2006 and 2008, the private debt to income ratio continued to grow - mostly from currencydenominated, therefore risky, foreign credits. The international financial and economic crisis hit Hungary first and hard in October 2008. Logically, the austerity plan of 2009 included a heavy reduction of short- and long-term pension expenditures.

During the long years of opposition (2002 to 2010), the right-of-center Fidesz party permanently attacked the left-of-centre government's popular as well as its unpopular measures: the former were too modest for the conservatives (in fact, they promised a 14th month benefit in 2006), the latter were too strict ("no need for austerity"). Partly due to this populistic political stance, the conservatives gained a supermajority in the parliament in May 2010. Rather than withdrawing their irresponsible promises, especially the introduction of a low, flat-rate personal income tax, the governing conservatives delivered on them.

After some awkward trials, the conservatives decided to close down the mandatory private pillar. The main reason behind this move was to gain access to the financial resources that would permit tax cuts (personal and corporate income taxes) without

3 "Progressivity" means the following: if A worked half as much as B and each hour earned half of B's wage, then A's pension would be much higher than a quarter $(1 / 2 \times 1 / 2)$ of B's pension. 
reducing public expenditures. Not content with the fact that pension contributions to the private second pillar pension associations (i.e. pension funds) have now become part of government revenues (equivalent to about 1.4 per cent of GDP), the government is willing to spend a large part of the nationalized capital of the pension associations for tax cuts. As a justification, they believe, or pretend to believe, in the high levels of financial risk associated with private pension investments and in the efficiency of the aforementioned tax cuts. While this article acknowledges the riskiness of pension investments, the economic risks of a mono-pillar pension system must be equally acknowledged. Furthermore, the efficiency of the tax reform can be contested and the abovementioned pension measures seriously threaten the future of the newly-enlarged public pension system.

There is a relatively rich literature on the Hungarian "permanent" pension reform: Augusztinovics and Martos (1997), Palacios and Rocha (1998), Augusztinovics (1999), Simonovits (2001), Augusztinovics et al. (2002), Czúcz and Pintér (2002), Rocha and Vittas (2002), Gál and Tarcali (2003), Simonovits (2008) and (2011), Gál, Iwasaki and Széman (2008), Guardianchich (2008) and Holtzer, ed. (2010).

The structure of the paper is as follows. The next section outlines the pre-reform state of the Hungarian public pension system. This is followed by an introduction to the partial privatization of the Hungarian pension system and then a short history of the Hungarian second pillar between 1998 and 2010. The economic and political changes that lead to the destruction of the second pillar are then outlined and the consequences of these are drawn. An Appendix shows the relative gains of those returning to the mono-pillar system and the relative losses of those who stay in the second pillar.

\section{THE HUNGARIAN PUBLIC PENSION SYSTEM UNTIL 1998}

We shall start our story by outlining the Hungarian pension system before 1998. 4 Hungary was (and is) an ageing country, with low fertility and relatively high age-specific adult mortality rates. As a result, the old-age dependency ratio (i.e. the ratio of the number of old-aged [aged 65 or older] to that of working age [aged 15 to 64]) was about 40 per cent in 1994 and is expected to rise to 52 per cent by 2030. This is not a particularly dramatic rise,

\footnotetext{
4 As additional background, Hungary is a middle-sized and middle-income country of some 10 million inhabitants with PPP per-capita GDP of about 60 per cent of the EU-27 average in the foregoing period. By 1997, the bulk of the economy had been privatized and after reaching the trough of the transformational depression in the years 1993 to 1996, the country had been developing significantly more rapidly than the EU-15 until 2006. In May 2004, Hungary joined the European Union with nine other countries, mostly ex-communist states. During 2007 and 2008, its GDP all but stagnated and sharply declined during the crisis of 2009.
} 
especially when one takes account of the low full benefit (retirement) ages of 1994; namely, age 55 (women) and age 60 (men).

During the communist era, Hungary had built up a relatively generous first pillar system, which was universal and was combined with a similarly public health care system (cf. Bokros and Dethier, 1998). By 1990, the ratio of public pension expenditures to GDP reached 10 per cent and has since remained around this value. (This is about the normal value in a mono-pillar system and is only about two-thirds of the peaks achieved in Poland or Italy.) As an important legacy of the communist system, the public pension system was highly progressive: higher earnings and longer employment increased the entry benefits much less than proportionally (see footnote 4), and as a consequence of the insufficient indexation of higher benefits, the value of the benefits in payment diminished progressively after retirement.

During the transformation of the economy, the employment rate (for those aged 15-64) dropped drastically (from 76 per cent in 1989 to 58 per cent in 1995) and has barely increased since. This change adversely influenced the pension system from two sides: various groups in the labour force chose early retirement, particularly the unemployed and those working in the hidden economy, causing a significant increase in the number of pensioners, while simultaneously reducing the number of potential active contributors. A simple consequence of this process was the surge in the so-called "system dependency ratio", that is, the ratio of the number of pensioners to the number of workers, from $5^{1}$ per cent to 84 per cent. 5

The consequence was direct: payroll tax rates had to be raised and benefit rates had to be cut. ${ }^{6}$

The transition from socialism to capitalism was accompanied by a significant temporary drop in real earnings, although one part of this drop was simply transformed into capital incomes. The appearance of double-digit inflation made a switch to the wage indexation of pension benefits inevitable in 1992. While the indexation of pensions more or less ensured the relative income position of pensioners with respect to workers, the progressive benefit formula of the entry pensions gave rise to widespread under-reporting of earnings and shorter episodes of contribution/lower density of contribution payments.

By 1995, a consensus had emerged: the Hungarian pension system needed reform. As is usual, there were two camps in Hungary: those who wanted to keep a pure public pension system by introducing parametric reforms (e.g. Augusztinovics and Martos, 1997)

5 One must underline that the system dependency ratio takes into account not only old-age pensioners, but survivor and disability beneficiaries as well.

${ }^{6}$ For example, in 1989 the previously differentiated contribution rates of 40-33-10 per cent were raised to a unified rate of 43 per cent; the replacement rate dropped from 66 per cent in 1990 to 59 per cent in 1996. 
and those who wanted to replace at least a large part of the public system with a private (and funded) pillar (e.g. Palacios and Rocha, 1998). The former view was convinced that the parametric reforms of the first pillar system were not only necessary but sufficient. In contrast, and following the ideas of the World Bank (1994), the latter view did not accept the sufficiency of such reforms. Moderate privatizers considered that partial privatization was necessary to deflect public attention way from the parallel parametric reforms of the public system, while radical privatizers believed in the superiority of any private system over any public one, including pensions, education, health care and transportation. 7

In 1997, Hungary chose partial privatization. Since then, except for Slovenia and the Czech Republic (the two richest transition economies in Central and Eastern Europe), the bulk of the countries in the region have followed suit. Of note, the Czech Republic currently plans to introduce a modest voluntary second pillar.

\section{THE HUNGARIAN PENSION REFORM: 1998}

Here we will elaborate on the compressed account of the Hungarian pension reform offered in the Introduction. The law adopting private individual accounts was passed by Parliament in the summer of 1997 and implemented on January 1, 1998. Let us consider the parametric and systemic reforms separately.

\section{PARAMETRIC REFORMS}

By definition, the parametric reforms were confined to the public pillar. The simplest element of the parametric reform has been the fast increase, in 1997, of the "full benefit age" from age 60 to age 62 (men) by 2001, and progressively from age 55 to age 62 (women) by 2008. The entry benefits of those who delay retirement beyond the full benefit age were raised significantly. Those who retire before reaching the full benefit age are to experience a significant reduction from $2013 .{ }^{8}$

Since 1998, the progressivity of the entry benefit formula has been diminishing steadily. Between 2000 and 2009, the already-in-payment benefits were increased on the basis of combined wage-price indexation. From 2013 the system will include a proportional entry benefit, gross rather than net, with a uniform accrual of 1.65 per cent

\footnotetext{
7 Various transition scenarios are modeled and compared in Kotlikoff (1997), Simonovits (2003, Chapter 15), and Feldstein (2005).

${ }^{8}$ In the interim, it is to be noted that the rules of transition are so generous that the bulk of retirees who have a sufficiently-long work history still retire well in advance of the full benefit age with almost a full benefit entitlement.
} 
for the mono-pillar (or 1.22 per cent for the mixed system). After 40 years of employment, the resulting pre-tax, mono-pillar entry benefit will be 66 per cent of the reference gross wage.

\section{Systemic reforms}

From the point of view of this article, the systemic reforms are more spectacular than the parametric reforms. In 1998, Hungary, a pioneer among the ex-communist countries in this regard, partially privatized its first pillar system. Rather than adding a new pillar on top of the existing "first pillar" system, the government "carved out" a mandatory private pillar from the old system. For the members of the combined system, roughly one-quarter of the total mandatory contribution ( 8 per cent of the gross wage) was to be channelled into the private pillar while roughly three-quarters (or 23 per cent) was directed to the public pillar.

The workers were free to join any private pension association and to switch associations at any time paying only minimal fees. As the private pillar was part of the mandatory system, the government monitored the operation of the private associations: its supervisory board (Hungarian Financial Supervisory Authority) ensured that the pension associations complied with the legal regulations. Moreover, originally there was a government guarantee behind them that limited members' loss to 6 per cent of the corresponding mono-pillar benefit. With time, this guarantee was discreetly withdrawn in 2002, but re-established in another guise in 2009.

Consistent with the mandatory character of the two-pillar system, after 15 years of participation the private pillar was also to pay retirees life annuities, to be computed on the basis of unisex life expectancy tables. Rather surprisingly, to make the private and the public entry benefits comparable, the law also required wage-price indexation of private life annuities, an impossible requirement.

Rather than confining privatization to old-age pensions alone (as in Poland), proportional fractions of the disability and survivor pensions were also transferred into the private domain. Those who became disabled were given the option of returning to the mono-pillar system. If ever a member of a private pension association died before retirement, his or her designated heirs could have inherited the accumulated capital of the deceased.

Participation in the mixed system was mandatory for those who entered the labour market after June 30, 1998, but optional for those who paid contributions to the first pillar system before 1998. Because of this, it would have taken decades before the mono-pillar system had disappeared completely. 
Although the socialist-liberal coalition government that introduced the reform preached the superiority of the private system over the public one, to save on transition costs it sought to confine participation in the mixed system primarily to younger cohorts. As an automatic tool for limiting participation, the government framed the transition rules so that subscribers to the mixed system lost about one-quarter of their contributions to the pre-reform system. About half of all workers joined the mixed system during the transition period, which lasted until August 31, 1999. These were drawn predominantly, but not exclusively, from younger cohorts. According to realistic projections, a significant part of those who joined the mixed system would have received lower total pensions than if they had stayed in the mono-pillar system, owing to the low efficiency of the private pillar (Simonovits, 2003, Table 5.2 and Figure 9.1).

The most pressing question surrounding a reform such as this is always who will bear the costs of transition. By design, the reduction of the projected values of the mono-pillar and the first pillar benefits, i.e. the parametric reform, along with the voluntarily-accepted partial loss in benefits payable to the older entrants who joined the mixed system, would have resulted in a considerable saving in public pension expenditures. But these reductions would not have eliminated the temporary financing gap that had arisen between current contributions and benefits. The reform government made a promise to finance the cost of transition from general revenues (including debt finance).

At the start, it was hoped that the partial privatization of the first pillar system would enhance compliance and draw workers out of the grey economy into the "world of labour". It is true that participation in any mandatory system depends strongly on the perceived relation between individual costs and benefits (Kotlikoff, 1997) and both pillars were much more transparent than the old system had ever been. But it was naive to believe (if anyone actually did believe) that workers from the grey economy would suddenly report their total earnings: for the "privilege" of contributing a mere 8 per cent of covered earnings to the private pension fund, while they would have to pay over 50 per cent of their gross wages for various contributions and taxes. This is hardly an enticing proposition. But even if the entire first pillar system had been privatized as in Chile, poorer workers could still not have afforded any contribution (Gill, Packard and Yermo, 2005).

We now turn to the most important pitfalls of the Hungarian (and other) structural pension reform(s), which became more and more transparent with the passage of time.

i) It is not easy to harmonize a private pillar and a public pillar, especially in a set-up where the private pillar is dominated by the public one. How can the government expect workers to contribute fully to a lower quality but dominant first pillar and a higher quality but modest second pillar? The simple slogan used at the time of "security via diversification" could not solve this problem. 
ii) Private pension funds or "associations", especially those based on individual rather than firm membership, have high operating costs.

iii) There are very few countries with mandatory private life annuities, and probably no mandatory fund pays price-indexed unisex annuities.

iv) It is obvious that during the transition the expenditures of the public pillar cannot be reduced as much as necessary to compensate for the loss of contributions that, henceforth, are directed to the private pillar (about 1.4 per cent of GDP in the 2000s). Economists are divided whether this cost of transition is an integral part of the government budget or not (Beetsma and Oksanen, 2006, 588-589).

\section{THE SHORT HISTORY OF THE HUNGARIAN SECOND PILLAR (1998 TO 2010)}

Turning from the plans to reality, a reassessment of the Hungarian pension reform (Orbán and Palotai, 2005 and Simonovits, 2008) confirmed that the hopes of the reformers were not realized. On the one hand, the populist governments have not followed the original blueprints and rather than containing the public expenditures on pensions they enlarged them in a spectacular way. For example, they introduced a 13th month benefit, without ensuring the necessary financing. Between 1998 and 2006, wages increased much more rapidly than prices, and technical measures were needed to contain the relative pension dynamics. On the other hand, the substandard results of the private pension associations would have probably diminished the total benefits of the members relative to those of nonmembers until 2050, unless operational costs had been contained in the long run. The most important steps in the history of the Hungarian second (and first) pillar(s) were as follows.

The socialist-liberal coalition government passed the two-pillar mandatory system into law in the summer of 1997. The law came into effect on January 1, 1998.

However, a new conservative government, which opposed the structural pension reform, came to power in May 1998. Its gradual efforts were geared to making the reform less popular. First it froze the contribution rate at 6 per cent, rather than raising it to 7 per cent in 1999 and 8 per cent in 2000 as it had been envisaged in the 1998 reform. Moreover, it used the transition cost as a pretext to cut back on public benefits, too. At the end of its four-year mandate, it made the return to the mono-pillar system possible; this became the default option in 2002. As a consequence, the guarantee was also eliminated. These measures already foreshadowed the drastic measures of 2010. 
The social-liberal coalition returned to power in 2002 and made entry into the mixed system mandatory again for newcomers to the labor market and opened entry into it for those younger than age 30. Forgetting the rules of fiscal prudence, it introduced the 13th month benefit, on a gradual basis, between 2003 and 2006 and, in the same period, raised the private contribution rate from 6 per cent to 8 per cent. Adding other popular programmes, the budget deficit and the current account deficit rose to untenable heights (both about 9 per cent of the GDP).

Initially, there were numerous pension associations. Rapidly, however, the bulk (more than 90 per cent) of both capital and membership became concentrated in the six biggest firms, each connected with large financial institutions - banks or insurance companies. During a period of steady economic growth (1998-2004), on average the Hungarian private pillar paid a real interest rate of zero per cent (Matits, 2004) - if one does not neglect the operating costs proportional to contributions and assets, as was the case in Hungary. It took ten years for the government to enforce through regulation these costs to 4.5 per cent and 0.8 per cent, respectively.

In 2004, Hungary entered the European Union (EU) and immediately was ordered to cut the budget deficit. The re-elected government successfully reduced the budget deficit from 9 per cent to 4 per cent between 2006 and 2008, but could not prevent firms or citizens from taking large private loans, mainly from abroad and in foreign denominations, especially in Swiss francs. As a result, the gross foreign debt ratio rose between 2004 and 2007 by 24 per cent, out of which 18 percent falling to the private debts. Meanwhile the gross government debt continued to rise well beyond the sacrosanct $60 \% .9$

It is characteristic of the negligence of Hungarian governments that it did not occur to the authorities to incorporate the transition costs of privatization into government revenues until 2004. When Hungary and other reform countries (e.g. Sweden and Poland) made a formal request in 2004, the EU authorized only a corresponding reduction in the government budget deficit for five years and at a diminishing rate.

Between 2007 and 2010, the pension associations were required to offer a range of portfolios, from conservative to aggressive growth funds, wherein the level of individual risk exposure was expected to decline as members approached retirement age.

During the international financial and economic crisis the Hungarian pension associations (both mandatory and voluntary) suffered terrible losses, but these have since been mostly recovered. As a by-product of this temporary crisis, the then Socialist government opened the door to enable a voluntary return to the mono-pillar system for

${ }_{9}$ See IMF and other statistics on the Hungarian accumulated foreign currency denominated private debts. 
those who were older than age 52 in 2009. It is worth recalling that members of older cohorts gave up one-quarter of their previous pension rights when they joined the mixed system, a loss that they have not been able to recover, especially in light of the turbulent global economy. As was expected, the pension associations also supported the voluntary return to the mono-pillar system, lest the first private retirees would be disappointed. Not understanding this issue, only half of the older members accepted this offer. ${ }^{10}$

We now arrive at the most pressing problem of mandatory funded systems: the payment of unisex inflation-proof life annuities. It took 12 years in Hungary for the government to come up with a hybrid solution: to transform the pseudo pension funds (i.e. pension associations) working in the form of cooperatives into real funds (more precisely, specialized insurance institutions) and provide two alternative unisex life annuities:

a) inflation-proof annuities, that were probably to be provided by the government; and b) risky life annuities, with only a nominal guarantee of subsequent benefits. Unfortunately, the then President of the Republic had misgivings about the correctness of this plan and sent it to the Constitutional Court just before the 2010 elections.

When the international financial and economic crisis arrived, Hungary was hit hard. Only the conditional loans of the EU and the International Monetary Fund (IMF) have saved the country from a complete financial meltdown. But these conditions required short-and long-term adjustments, including those in the pension system: elimination of the 13th month benefit; the replacement of wage-price indexation by, essentially, price indexation; and raising the full-benefit retirement age (men and women) from age 62 to age 65 between 2012 and 2018, in fact, between 2014 and 2024.

\section{THE DESTRUCTION OF THE SECOND PILLAR}

For a long time, it was an open question what the new government would do with the economy after the conservative Fidesz party gained 68 per cent of the seats in the parliament at the elections in April 2010. In opposition (between 2002 and 2010), the conservatives opposed every restriction (austerity measures) in general and voted against the elimination of the $13^{\text {th }}$ month benefit in 2009 in particular. ${ }^{11}$ The new government could hardly leave the path of "superfluous restrictions" started in 2006 by the socialist-

\footnotetext{
${ }^{10}$ Among the other half of member that remained was the present economic minister, who executed the "nationalization" of the pension associations at the end of 2010.

${ }^{11}$ Note, however, that in a "hidden" television interview, as the leader of the then opposition, Orbán admitted that there was no way to re-establish the 13th month benefit in the near future.
} 
liberal government and it was equally difficult to admit that they "did not know" what they were talking about regarding the superfluous restrictions while being in the opposition.

At the beginning of June 2010, the new government tried to increase its room for manoeuvre. The new prime minister, Viktor Orbán, wanted to increase the maximum permitted budget deficit in terms of GDP from the earlier 3.8 per cent to 7.5 per cent, but and also because of the impact of the Greek crisis and the permanent overspending of Hungary - the European Commission insisted on the original deficit ceiling and Hungary had to accept the conditions. To reduce the immediate pressure on public finances, the government discontinued its relationship with the IMF, though the country must still repay the conditional loans (about 13 billion euros) in the coming years.

In August 2010, together with eight other EU countries, Hungary asked the EU to modify its earlier decisions of 2005 and take into full account the transition costs of pension privatization in the budget deficit and the government debt. The rapid EU decision was a conditional "yes" and "no": yes for Poland, with a lower government debt ratio; and no for Hungary, with a higher government debt ratio. ${ }^{12}$

At the same time, the Hungarian Constitutional Court largely upheld the previous government's original plan for the transformation of pension associations into genuine pension funds. During the summer of 2010, it appeared that the ruling conservatives would have to extricate themselves from the trap they set for their opponents. Events, however, took a different turn.

Most notably, in mid-October 2010, Prime Minister Orbán announced a spectacular personal income tax reform, making the formerly quite progressive tax schedule almost linear and low (ending with a rate of 16 per cent), between 2010 and 2013. Like President Reagan in the United States in the 1980s, the Hungarian Prime Minister seems to believe that these measures will raise the GDP growth rate from 3 per cent to 5 per cent in only three years and increase the activity rate from 60 per cent to 80 per cent in ten years. Furthermore, there is an expectation that generous tax credits for families with three children will raise the total fertility rate from 1.3 to 1.7 . To finance the reduction of the personal and corporate income tax and further delay much needed cuts in public spending (which is still equivalent to about 50 per cent of GDP, and thus much higher than that of other similar countries), the new government levied massive extraordinary taxes on competitive firms and banks. The extraordinary taxes will constraint future growth.

Between May and October of 2010, there were already rumours on the Web that the new government was considering the reduction or elimination of the second pillar and

${ }_{12}$ Strangely enough, the three Baltic countries (Latvia, Estonia and Lithuania) have already temporarily suspended the transfer of contributions to private pension funds, alleviating budget tensions. 
these rumours were never refuted. Moreover, according to reliable private sources, the EU and the IMF "openly" opposed the government's plans on nationalization. Such a nationalization increases the actual maximum permitted budget deficit by 1.4 per cent of GDP and the released accumulated capital of the pension associations promises an easy bounty.

After a long suspense, on October 13 2010, Prime Minister Orbán announced the temporary suspension of the transfer of the private contributions to the associations (through the Hungarian Tax Authority) for 14 months and the right of insured workers to voluntarily return to the mono-pillar system. Without any discussion, the supermajority of parliament voted for these laws with long-lasting effects. Two weeks later, the prime minister took the next step and announced the de facto closing down of the private pension associations forever. Although members were "allowed" to stay in the mixed system and contribute 10 per cent rather than 8 per cent to their private associations, the remaining members were in turn obligated to renounce their rights to all their hardearned contributions (at a rate of 24 per cent of gross wages) that would have accrued in the public pillar after 2011. The members were given two months (including two weeks around Christmas) to decide. An Appendix provides simplified calculations on the relative gains for returning to the mono-pillar system and the relative losses of staying in the private pillar as a function of the current age. For example, a typical worker of current age 40 gains 5 per cent of the mono-pillar benefit by returning, while he or she loses 40 per cent of the mono-pillar benefit by staying. The letter of the new law would take away even the disability, survivor and health care benefits of those staying in the second pillar but probably the lawmaker will eliminate this glaring anomaly.

In line with the tenets of behavioural economics, the government made the automatic return or entry into the mono-pillar system the default option. Moreover, those returning to the mono-pillar system and who have positive real returns on their accounts (the difference between the real values of the pension capital and of the total contributions, for every worker), can collect these returns; those with negative real returns will be compensated on their public accounts for these losses. For the entire country, there were only 30 designated points of contact where those members who wished to stay in the pure second pillar could personally and formally re-affirm their intention to do so. In the end, 3 per cent of the membership decided to remain in the pure second pillar, most of them deciding at the last minute. Since most remaining members are young, they may believe that they have enough time to wait for the eventual reversal of the law. It is characteristic of the government's cynicism that the official evaluation of this outcome was that the great majority of the ex-pension association members supported the government by "choosing" the mono-pillar system. On the other hand, if the mandatory private pillar had been 
extremely efficient and attractive, then the 3 million members could have organized mass demonstrations against the government decision and could have compelled the government to renounce its decision.

To date, there would appear to have been no formal estimation of the fiscal implications of the reform, let alone how the administration will manage the challenges arising from the dual programmes within the mono-pillar system. For example, the remaining pension wealth of the pension associations may be 10 per cent rather than 3 per cent of the total (more than 3 times the per capita average), i.e. equal to about 1 per cent of the GDP. There are estimates that the total of positive real returns may amount to 1 per cent of GDP. Moreover, the nationalized pension capital (9 per cent rather than the original 11 per cent of GDP) will be used not only for a reduction of the budget deficit (5 per cent of GDP), but for making room for a radical tax cut (cc. 4 per cent of GDP during three years). Finally, the implicit government debt will be increased by the gains in future pension entitlements of those returning to the mono-pillar.

In anticipating the opposition's application to the Constitutional Court in the defence of the private pension accounts, the government has already curtailed a substantial part of the jurisdiction of the Constitutional Court, making any legal reversal illusory. The government has sacrificed the future on the altar of the present. Once more, the future of the Hungarian pension system looks dark.

It is worth remembering that the Polish government also drastically reduced, but did not eliminate the contributions to, the second pillar in December 2010. In this case, the EU promised to tolerate Polish practice, effectively saving the Polish second pillar from destruction.

\section{CONCLUSIONS}

To conclude, a number of observations can be presented. Partial privatization of a mature and universal public system is feasible even in middle-income countries like Hungary and other ex-communist countries. Judging by the number of affiliates who joined voluntarily (about half of the workforce), such a transition can be quite popular, at least for a while. Individuals, however, may not understand fully the disadvantages of joining the mixed system - in Hungary, those who joined the pension associations voluntarily ceded onequarter of their previously-gained pension rights. From the perspective of employers, with the support of ITC technologies, even small firms are able to direct the monthly private contributions of their workers to various funds and well-developed pension funds are able 
to invest even these relatively small individual contributions (equivalent to around USD 80 per month).

For reforms to be accepted as legitimate by the population, pension promises need to be kept. No less important is the appropriate regulation and good governance of the pension system. An often-cited argument in favour of creating private pension pillars is to diversify risk, including reducing political risk.

However, governments can also target the accumulated capital of pension funds as a source of finance to bankroll projects without having to raise personal income tax rates or reduce public expenditures. This temptation may be especially strong in times of crises when short-terms needs overshadow long-terms objectives.

From this perspective, Hungary is a typical case how not to do pension reforms and counter-reforms. 


\section{APPENDIX: RELATIVE GAINS AND LOSSES}

This Appendix calculates the relative gains ${ }^{13}$ of those individuals who return to the monopillar system and the corresponding losses of those who stay in the second pillar as a function of age, pessimistically assuming that the present discriminatory law remains valid until all the participants die. (Nevertheless, we assume that nobody, who stays in the private pillar, loses his or her already acquired rights even if he or she had less than 15 or 20 years of employment by 2010.) To avoid the excessive complexity of the reform and counter-reform, we greatly simplify the situation. We concentrate on a wage earner who always earns the nationwide average or its scalar. Assuming that the efficiency of the private pillar is the same as that of the public, we need the following notations: the dates of start and of the end of the second pillar: $\mathrm{T}_{1}=1998$ and $\mathrm{T}_{2}=2010$. Our fictitious hero had age $A$ in $T_{2}$, i.e. he was born in year $T_{2}-A$, started to work in year $T_{2}-A+L$, and retired in year $\mathrm{T}_{2}-\mathrm{A}+\mathrm{L}+\mathrm{R}$. We only consider those who were members of private pension associations in 2010, i.e. $\mathrm{T}_{2}-\mathrm{A}+\mathrm{L}+\mathrm{R}>\mathrm{T}_{2}$, i.e. $\mathrm{A}<\mathrm{L}+\mathrm{R}$. We distinguish those who worked in $T_{1}$ or not: either $T_{2}-A+L<T_{1}$ or $T_{2}-A+L \geq T_{1}$, i.e. either $A>T_{2}-T_{1}+L$ or $A$ $\leq \mathrm{T}_{2}-\mathrm{T}_{1}+\mathrm{L}$.

What is the expected gain for somebody who returns to the mono-pillar system? He or she recoups 0.25 times his or her annual pension during the pre-reform years, their numbers being $\left(T_{1}-T_{2}+A-L\right)_{+}$, where subindex + denotes the positive part of a real number. This gain is to be compared to the unit mono pension, accruing for $\mathrm{R}$ years. In formula:

$$
\mathrm{G}=0.25\left(\mathrm{~T}_{1}-\mathrm{T}_{2}+\mathrm{A}-\mathrm{L}\right)_{+} / \mathrm{R}
$$

What is the expected loss for somebody who stays in the private pillar? On the one hand, he or she renounces his or her gains accruing from the annulled losses mentioned above. On the other hand, he or she suffers new losses, renouncing 0.7 times of the monopillar pension rights earned in the years of the counter-reform, their number being $L+R-$ A. In formula:

$$
\mathrm{V}=\mathrm{G}+0.7(\mathrm{~L}+\mathrm{R}-\mathrm{A}) / \mathrm{R} \text {. }
$$

The relative values of the gains of returning and the losses of staying are given in Table A1.

\footnotetext{
13 This gain is the annulled losses suffered by joining voluntarily the mixed system in 1998-1999, when any worker ceded one-quarter of his previous pension rights. The positive real returns cannot be modelled at the moment.
} 
Table A1.

\section{Current age, gain and loss}

$\begin{array}{lll}\begin{array}{l}\text { Current } \\ \text { age } \\ \text { (year) }\end{array} & \begin{array}{l}\text { Gain from } \\ \text { returning } \\ (\%)\end{array} & \begin{array}{l}\text { Loss } \\ \text { of staying } \\ (\%)\end{array} \\ 25 & \text { 0.0 } & 61.3 \\ 30 & 0.0 & 52.5 \\ 35 & 1.9 & 45.6 \\ 40 & 5.0 & 40.0 \\ 45 & 8.1 & 34.4 \\ 50 & 11.3 & 28.8 \\ 55 & 14.4 & 23.1 \\ 60 & 17.5 & 17.5\end{array}$

It can be seen that by raising the current age from 30 to 60 , the relative gain increases steeply, from zero to 17.5 per cent of the mono-pillar benefit. The relative loss of staying in the private pillar decreases with the current age: it is 61 per cent for those aged 25 and 17.5 per cent for those aged 6o, the latter being equal to the gain of returning. 


\section{BIBLIOGRAPHY}

Augusztinovics, M. 1999. "Pension Systems and Reforms - Britain, Hungary, Italy, Poland, Sweden”, in European J ournal of Social Security, Vol. 1, No.4, pp. 351-382.

Augusztinovics, M., Gál, R. I., Matits, Á., Máté, L., Simonovits, A., Stahl, J., 2002. "The Hungarian Pension System before and after the 1998 Reform", in E Fultz (ed.), Pension Reform in Central and Eastern Europe, Vol. 1-2, Geneva, ILO. pp. 25-93.

Augusztinovics, M.; Martos, B. 1997. "Pension reform: calculations and conclusions", in Acta Oeconomica Vol. 48, Nos. 1-2, 119-160.

Barr, N.; Diamond, P. 2008. Reforming pensions: Principles and policy choices, Oxford, Oxford University Press.

Beetsma, R.; Oksanen, H. 2008. "Pensions under ageing populations and the EU stability and growth pact”, in CESifo Economic Studies, Vol. 54, No. 4, 563-592.

Bokros, L.; Dethier J. J. (eds.). 1998. Public finance reform during the transition: The experience of Hungary, Washington, DC, World Bank.

Czúcz, O.; Pintér, M. 2002. "Transformation of old-age security in Hungary", in W. Schmähl; S. Horstmann (eds.). Transformation of pension systems in Central and Eastern Europe, Cheltenham, Edgar Elgar. pp. 277-304.

Diamond,P.; Orszag, M. 2005. "Saving social security", in Journal of Economic Perspectives, Vol. 19, No. 2, pp. 11-32.

Feldstein, M. 2005. "Structural reform of social security", in Journal of Economic Perspectives, Vol. 19, No. 2, pp.33-55.

Feldstein, M.; Siebert, H. (eds.). 2002. Social security reforms in Europe, Chicago, IL: Chicago University Press.

Fultz, E. (ed.). 2002. Pension reform in Central and Eastern Europe, Vol. 1-2, Geneva, International Labour Office.

Gál, R. I.; Tarcali, G. 2003. "Pension reform and intergenerational redistribution in Hungary", in The (J apanese) Economic Review, Vol. 54, No. 3, pp. 237-247.

Gál, R. I.; Iwasaki, I; Széman, Zs. 2008. Assessing intergenerational equity: An interdisciplinary study of aging and pension reform in Hungary, Budapest, Akadémiai Kiadó.

Gill, S. I.; Packard, T.; Yermo, J. 2005. Keeping the promise of social security in Latin America, Palo Alto, Stanford UP and Washington, DC, World Bank.

Guardiancich, I. 2008. "How not to implement: Hungarian pension reform in an institutional perspective (TIGER Working Paper 110), Warsaw.

Holtzer, P. (ed.). 2010. Report of the pension and old-age round table on its activities between March 2007 and November 2009, Budapest, Hungarian Government.

Kotlikoff, L. 1997. "Privatization of social security: How it works and why it matters?" in J. Poterba, (ed.) Tax Policy and the Economy 10, Cambridge, MA, MIT Press.

Matits, Á. 2004. Practical experience with the second pillar of the Hungarian mandatory pension system (Paper delivered at a conference on pension systems organized by the International Labour Office, Budapest, December 9-11).

Müller, K. 1999. The political economy of pension reform in Central-Eastern Europe, Cheltenham, UK, Edward Elgar. 
Müller, K. 2003. Privatising old-age security: Latin America and Eastern Europe compared, Cheltenham, UK, Edward Elgar.

Müller, K., Ryll, A. and Wagener, H. J. eds. (1999): Transformation of social security: Pensions in Central-Eastern Europe, Heidelberg, Physica.

Orbán, G.; Palotai, D. 2005. The sustainability of the Hungarian pension system: A reassessment (Budapest, MNB Occasional Papers 40), Central Bank of Hungary.

Orszag, P.; Stiglitz, J. E. 2001. "Rethinking pension reform: Ten myths about social security systems", in R. Holzmann, R.; J. E. Stiglitz, ( eds). New ideas about old-age security: Toward sustainable pension systems in the 21st Century. Washington, DC, World Bank.

Palacios, R.; Rocha, R. 1998. “The Hungarian pension system in transition”, in L. Bokros; J. J. Dethier (eds.). Public finance reform during the transition: The experience of Hungary, Washington, DC, World Bank.

Rocha, R.; Vittas, D. 2002. "The Hungarian pension reform: A preliminary assessment", in M. Feldstein, M. and H. Siebert (eds.). Social security reforms in Europe, Chicago, IL: Chicago University Press.

Schmähl, W.; S. Horstmann (eds.). 2002. Transformation of pension systems in Central and Eastern Europe, Cheltenham, Edgar Elgar.

Simonovits, A. 1999. "The new Hungarian pension system and its problems”, in K. Müller; A. Ryll; H. J. Wagener, (eds.). Transformation of Socials Security: Pensions in Central-Eastern Europe, Heidelberg, Physica.

Simonovits, A. 2001. "Partial privatization of a pension system: Lessons from Hungary", in International J ournal of Development, Vol. 12, No. 4, pp. 519-529.

Simonovits, A. 2003. Modeling Pension Systems, Oxford, Palgrave Macmillan.

Simonovits, A. 2008. "The pay-as-you-go system and permanent reform: The first pillar," in R. I. Gál; I. Iwasaki; Zs. Széman. 2008. Assessing intergenerational equity: An interdisciplinary study of aging and pension reform in Hungary, Budapest, Akadémiai Kiadó.

Simonovits, A. 2009. Hungarian pension system and its reform (IEHAS Working Paper 09-088), Budapest, Institute of Economics, Hungarian Academy of Sciences.

Simonovits, A. 2011. "Impact of the economic and financial crisis on pension systems in Central and Eastern Europe: Hungary, in Zeitschrift für Sozialreform (J ournal of Social Policy Research) (forthcoming).

World Bank. 1994. Averting the old age crisis: Policies to protect the old and promote growth (Policy Research Report), Oxford, Oxford University Press.

World Bank. 2006. Pension reforms and the development of pension systems: An evaluation of World Bank assistance, Washington DC, Independent Evaluation Group, World Bank. 
Discussion Papers published in 2011

Mihályi Péter: Utolérési kísérletek Magyarországon, 1870-2030. MT-DP 2011/1

Zsolt Darvas - Jean Pisani-Ferry: The Threat of 'Currency Wars': A European Perspective. MT-DP 2011/2

Zsolt Darvas: Beyond the Crisis: Prospects for Emerging Europe. MT-DP 2011/3

Barnabás M. Garay - András Simonovits - János Tóth: Local Interaction in Tax Evasion. MT-DP 2011/4

Maria Csanadi: Varieties of System Transformations and Their Structural Background Based on the IPS Model. MT-DP 2011/5

Mária Lackó: The Poor Health Status of the Hungarians; Comparative Macro-Analysis of the Likely Explanatory Factors on Hungarian and Austrian Data, 1960-2004. MT-DP 2011/6

Fazekas Károly: Közgazdasági kutatások szerepe az oktatási rendszerek fejlesztésében. MT-DP 2011/7

Gábor Kézdi - Gergely Csorba: Estimating the Lock-in Effects of Switching Costs from Firm-Level Data. MT-DP 2011/8

Antal-Pomázi Krisztina: A kis- és középvállalkozások növekedését meghatározó tényezők - A különböző finanszírozási formák hatása a vállalati növekedésre. MT-DP 2011/9

Zsolt Darvas - Jean Pisani-Ferry - André Sapir: A Comprehensive Approach to the Euro-Area Debt Crisis. MT-DP 2011/10

András Simonovits: International Economic Crisis and the Hungarian Pension Reform. MT-DP 2011/10 